\title{
Estimating the Price and Income Elasticities of Crude Oil Import Demand for Turkey
}

\author{
İsmail Kavaz ${ }^{\circledR}$ \\ Bingöl University
}

\begin{abstract}
In this study, the price and income elasticities of Turkey's imported crude oil demand are analysed. In this context, annual time series data covering the period 1970-2018 are preferred for imported crude oil, real price for crude oil and real GDP. As known, Turkey is an energy dependent country especially in fossil fuels. Therefore, estimating Turkey's crude oil demand equations is very significant to analyse the consumption trend and the future expectations in terms of this energy resource. This study employs Harvey's Structural Time Series Modelling Method (STSM) with the underlying energy demand trend (UEDT) concept for determining the relations among income, price and crude oil import demand. The empirical results show that the income and price elasticities of crude oil demand in Turkey are 0.66 and -0.11 , respectively. The estimated elasticities suggest that income and price elasticities for the imported crude oil demand are inelastic.
\end{abstract}

Key words: Crude Oil Import Demand, Elasticity Estimates, Turkey

JEL Classifications: C22, Q41

\section{INTRODUCTION}

Energy is a very significant driver for the modern economies in today's world. Therefore, estimating how much energy that needs to be consumed is as important as energy itself. After the first oil shock in 1973, studies measuring the energy demand have gained popularity since countries have wanted to know the quantity of energy that they need. Since then, government institutions, academicians and actors in the market have been studying on modelling and forecasting the demand for energy to contribute the security of energy supply. The reason behind this argument is that the energy resources are finite and unsustainable. Since energy scarcity and security are two major issues that developing economies have been facing, the appropriate and correct energy demand modelling procedures become significant.

This study mainly focused on the price and income elasticities of imported crude oil in Turkey. For this reason, the basic determinants of Turkey's imported crude oil are modelled by using a specific econometric method. To identify the effects of price and income on Turkey's crude oil demand, the Structural Time Series Modelling (STSM) method is preferred in this study. The STSM approach has several advantages comparing with the conventional econometric models. The main advantage of this method is that the researcher can add the unobservable stochastic trend into the model by using the Underlying Energy Demand Trend (UEDT) concept with the STSM procedure. Consequently, adding a stochastic trend to the model as a determinant of technical progress might yield more reliable and unbiased estimations for the elasticities. This is a very important priority for countries like Turkey since the country's dependency on energy resources is very high.

\footnotetext{
${ }^{\circledR}$ İsmail Kavaz, PhD, Department of Economics, Bingöl University, (email: i_kavaz@hotmail.com). ORCID: $000000023044795 \mathrm{X}$
} 
Turkey's energy dependence to external resources is almost $75 \%$. Moreover, this dependency is mainly on fossil fuels. As a result of this extreme external dependence rate, Turkey's energy expenditures are considerably high. For this reason, modelling and forecasting accurate energy demand for Turkey is as crucial as decreasing this high energy dependence by using domestic sources.

Crude oil is one of the fossil resources that has a very significant role for developed and developing economies. The demand for oil increases as the countries urbanize. In this context, the industrial development is highly correlated with oil consumption. Therefore, while the countries' growth rates increase, their energy demand increases as well.

Parallel with the global trend, the demand for crude oil has an important place in primary energy consumption in Turkey. Figure 1.1 presents the distribution of primary energy consumption by source in Turkey for the year of 2018. As it is shown in the figure, approximately $30 \%$ of total primary energy demand consists of oil. Therefore, oil can be said one of the major energy resources in Turkey and the determinant of oil demand should be examined carefully.

Figure 1.1 Primary Energy Consumption by Source in Turkey $(\%, 2018)$

Source: MENR (2018).

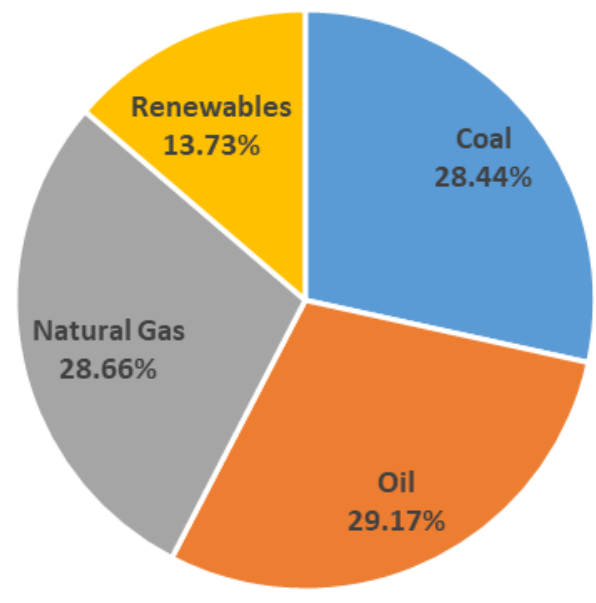

Figure 1.2 Turkey's Total Oil Consumption by Sectors $(\%, 2018)$

Source: MENR (2018).

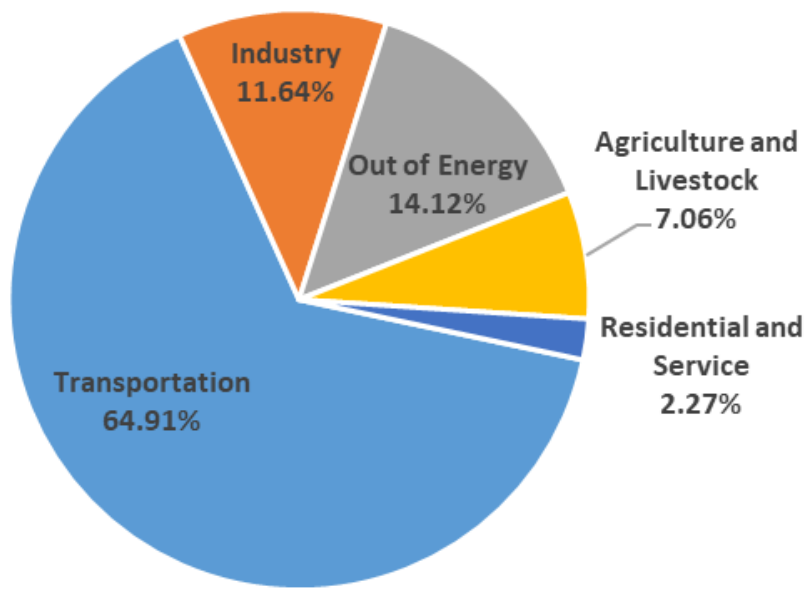

In addition, the sectoral oil consumption trend of Turkey can give another clue about the usage of this energy resource in the country. In Figure 1.2, oil consumption of Turkey based on the 
sectors is given. The most usage of oil is in the transportation sector. Almost $65 \%$ of total oil consumption is made in this field. Besides, while the out of energy consumption of oil constitutes about $15 \%$ of total oil demand, nearly $12 \%$ belongs to the industrial sector.

On the other hand, as it is mentioned in the beginning, Turkey is dependent to the external suppliers on crude oil. In Table 1.1, the main oil data is presented. As can be seen from the table, Turkey's import dependency has been increasing over the period. Recently, this rate is more than $90 \%$ and the domestic production is not sufficient to reduce the foreign dependency. Furthermore, as demand for oil is increasing over time, this high dependency rate constitutes a risky situation to Turkey in terms of energy supply security. In short, since the issue of crude oil is very critical for Turkey, the demand trend and the elasticity estimates for this energy resource should be analysed carefully.

\begin{tabular}{|c|c|c|c|c|c|c|c|c|c|c|c|}
\hline & 1970 & 1975 & 1980 & 1985 & 1990 & 1995 & 2000 & 2005 & 2010 & 2015 & 2018 \\
\hline Domestic Production & 3557 & 3250 & 2447 & 2216 & 3717 & 3516 & 2887 & 2395 & 2496 & 2516 & 2994 \\
\hline Import & 8649 & 10988 & 14339 & 17574 & 22396 & 27169 & 32001 & 35519 & 35818 & 38361 & 41913 \\
\hline Demand & 12206 & 14238 & 16786 & 19709 & 26113 & 30685 & 34888 & 37914 & 38314 & 40877 & 44907 \\
\hline Import Dependency & $70,8 \%$ & $77,1 \%$ & $85,4 \%$ & $89,1 \%$ & $85,8 \%$ & $88,5 \%$ & $91,7 \%$ & $93,6 \%$ & $93,5 \%$ & $93,8 \%$ & $93,3 \%$ \\
\hline
\end{tabular}

Table 1.1 Key Oil Data of Turkey.

Source: MENR Energy Balance Sheets (MENR, 2018).

Note: The quantities are in thousands of tonnes.

There are several crude oil import demand studies in the literature which are presented in the following parts. However, none of this studies have used the STSM/UEDT method to analyse the price and income elasticities of the crude oil import demand in Turkey. Therefore, as far as is known, this study is the first to estimate the price and income elasticities of Turkey's crude oil import demand by using STSM/UEDT concept. In this sense, this paper is expected to contribute the literature. More than this, the main aim of this study is to obtain reliable, significant and consistent estimates of price and income elasticities.

The outline of this paper is as follows. Section 2 is the literature review part. Section 3 presents the methodological framework and data. In section 4, the empirical results are given. Finally, section 5 summarises and concludes.

\section{LITERATURE REVIEW}

In the literature of energy economics, there is a considerable amount of studies related to the crude oil demand. In these studies, the variables such as price, income, population and air condition are used to analyse the effect of these parameters on crude oil demand. (Altinay, 2007; Ghosh, 2009; Ziramba, 2010, Öztürk and Arısoy, 2016; Khalil Jebran et al., 2017; Dash et al., 2018). In parallel with the existing literature, this study mainly focused the impacts of price and income on the crude oil demand.

In the oil demand literature, researchers have aimed to analyse the relationship between oil consumption and macroeconomic variables (Sadorsky, 1999). Since the crude oil is one of the most important energy resources in the world, especially the price and income variations on demand are considering carefully. In the recent period, especially the increasing energy demand of the developing economies has been examining frequently.

When the literature is reviewed as a whole, it can be said that different results were obtained in the studies examining the energy demand. This is because of the variety of method used, 
country or region investigated, variables included, period analysed, etc. Some studies have used time series analyses, whereas some have employed panel and cross-sectional data methods. In this part of the paper, first, some selected studies will be given related to countries that dependent the importers on crude oil like Turkey. Then studies regarding Turkey's crude oil import demand will be presented.

One of the most cited paper in the field of crude oil import demand belongs to Ghosh (2009). He established an equilibrium relation among crude oil import, income and price for India by using Autoregressive Distributed Lag (ARDL) Bounds Testing approach. Empirical results showed that the price elasticities both for short and long terms are found as statistically insignificant. On the other hand, the long run income elasticity is estimated as 1.97 which is considerably high. This elastic income elasticity shows that the country's crude oil demand is very sensitive to the income changes in the long term. Ziramba (2010) analysed the real price and income elasticities of crude oil import demand for South Africa. By using the Johansen cointegration method, he found the long run price and income elasticities as -0.14 and 0.42 , respectively. Khalil Jebran et al. (2017) estimated the price and income elasticities of crude oil demand in Pakistan by using the data between 1981 and 2013. They used ARDL Bounds Testing method. The short run elasticities are found as -0.59 for price and 0.80 for income. On the other hand, they estimated the long run price and income elasticities as -1.06 and 3.35, respectively. Dash et al. (2018) examined the effect of price and economic growth on crude oil demand for India again, over the period of 1997-2016. They found the price and income elasticities as -0.43 and 0.83 respectively, by using the structural VAR analysis. One recent study by Fatima et al. (2019) analysed the relationship between oil price, oil reserve, economic growth and oil consumption in China over the period between 1980-2015 by using the Structural Time Series Modelling method. They established two different model to estimate the elasticities. In the first model, the price and income elasticities are found as -0.04 and 0.5 , respectively. In the second model while they estimated the price elasticity equal to the first model, the income elasticity is found as 0.11 . In addition to the elasticity estimates, they predicted the possible future oil demand for China as 9.9 thousand barrels per day by 2025 .

Studies related to the crude oil import demand have also been done for Turkey in recent years. Crude oil is one of the main energy sources and plays a critical role in the economic development of Turkey. Therefore, from the mid-2000s onwards, the number of crude oil import demand studies has increased in Turkey. The main ones of these studies are presented below.

Altınay (2007) used the ARDL Bounds Testing approach to estimate the short and long run price and income elasticities of import demand for crude oil in Turkey. First, the long run parameters were estimated by ARDL method and then the short run variables were estimated by the Error Correction Model. Moreover, diagnostic tests were employed to analyse serial correlation, heteroscedasticity, functional form misspecification, and non-normal errors. In addition, Altınay (2007) used CUSUM and CUSUMQ tests to check the stability of the model. For the period between 1980 and 2005, he found the short and long terms income elasticities as 0.63 and 0.60 , while the short and long run price elasticities were calculated as -0.10 and -0.18 , respectively. Altınay (2007) stated that the income and price elasticities of import demand for crude oil were inelastic for both short and long term in Turkey.

Similar to Altınay (2007), Solak and Beşkaya (2013) also modelled the ARDL approach to cointegration for estimating the short and long run price and income elasticities of net oil imports in Turkey. By using the data between 1970 and 2010, they first used Augmented Unit 
Root test to analyse the stationarity of the series and then the ARDL Bounds Testing to cointegration method was employed. They found the short run relationship by ARDL Error Correction Model. Furthermore, they utilised CUSUM and CUSUMQ tests to examine the stability of the parameters. As a result, the short and long term income elasticities were estimated as 1.11 and 0.67 , respectively. The price elasticities in both the short and long run were found to be negative and statistically insignificant. The authors concluded that price variable has no effect on net oil imports in Turkey over the period 1970 to 2010.

Yapraklı and Kaplan (2015) re-examined the long-run price and income elasticities of Turkish crude oil import demand by using a different method, namely multi-structural breaks analysis. The quantities of imported crude oil were used as a dependent variable in the model. Furthermore, nominal prices of crude oil and GDP were used as independent variables. They first checked the variables for unit roots and as a result of unit root test they employed cointegration test. These two tests supported strong evidence of structural breaks. Finally, they adopted Dynamic Ordinary Least Squares (DOLS) method to analyse the long run elasticities. For the period between 1970 and 2013, Yaprakli and Kaplan (2015) estimated the long run price and income elasticities for Turkey to be -0.25 and 0.18 , respectively. Like Altınay (2007), they concluded that the price and income elasticities of demand for crude oil import are inelastic in the long run.

Different from the above mentioned studies, Öztürk and Arısoy (2016) used a dynamic framework of Time-Varying Parameters approach to investigate Turkey's crude oil import demand. They determined the quantity of imported crude oil as dependent variable whereas the real GDP and the real price of crude oil as independent variables in their model. They used annual time series data for the period 1966-2012 and found the statistically significant income elasticity as 1.18 . On the other hand, their price elasticity was statistically insignificant. Öztürk and Arisoy (2016) indicated that the quantity of imported crude oil is more responsive to changes in the income level than the price movements for Turkey. In addition, they specified that the imported crude oil is a normal good and the crude oil import demand grows higher than the change in income level.

\begin{tabular}{|c|c|c|c|c|}
\hline Author(s) & Period/Country & Methods Used & Study Focus & Results \\
\hline Altınay (2007) & $\begin{array}{l}\text { 1980-2005 } \\
\text { (Turkey) }\end{array}$ & $\begin{array}{l}\text { ARDL Bounds } \\
\text { Testing } \\
\text { Approach }\end{array}$ & $\begin{array}{l}\text { Crude Oil } \\
\text { Import } \\
\text { Demand }\end{array}$ & $\begin{array}{l}\text { The short- and long-run income elasticities are } 0.63 \text { and } \\
0.60 \text {, while the short- and long-run price elasticities are } \\
-0.10 \text { and }-0.18 \text {, respectively. }\end{array}$ \\
\hline $\begin{array}{l}\text { Solak and } \\
\text { Beşkaya (2013) }\end{array}$ & $\begin{array}{l}\text { 1970-2010 } \\
\text { (Turkey) }\end{array}$ & $\begin{array}{l}\text { ARDL Bounds } \\
\text { Testing } \\
\text { Approach }\end{array}$ & $\begin{array}{l}\text { Net Oil } \\
\text { Imports } \\
\text { Demand }\end{array}$ & $\begin{array}{l}\text { The short-and long-run income elasticities are } 1.11 \text { and } \\
0.67 \text {, respectively. The price elasticities in both short- } \\
\text { and long-term were found to be negative and } \\
\text { statistically insignificant }(-0.03 \text { and }-0.11) \text {. }\end{array}$ \\
\hline $\begin{array}{l}\text { Yapraklı and } \\
\text { Kaplan (2015) }\end{array}$ & $\begin{array}{l}\text { 1970-2013 } \\
\text { (Turkey) }\end{array}$ & $\begin{array}{l}\text { Multi-structural } \\
\text { Breaks Analysis }\end{array}$ & $\begin{array}{l}\text { Crude Oil } \\
\text { Import } \\
\text { Demand }\end{array}$ & $\begin{array}{l}\text { The long-run price and income elasticities of import } \\
\text { demand for crude oil are }-0.25 \text { and } 0.18 \text {, respectively. }\end{array}$ \\
\hline $\begin{array}{l}\text { Öztürk and } \\
\text { Arısoy (2016) }\end{array}$ & $\begin{array}{l}\text { 1966-2012 } \\
\text { (Turkey) }\end{array}$ & $\begin{array}{l}\text { Time-Varying } \\
\text { Parameters } \\
\text { Approach }\end{array}$ & $\begin{array}{l}\text { Crude Oil } \\
\text { Import } \\
\text { Demand }\end{array}$ & $\begin{array}{l}\text { The income elasticity is } 1.18 \text {. The price elasticity is } \\
\text { statistically insignificant }(-0.02) \text {. }\end{array}$ \\
\hline $\begin{array}{l}\text { Görüş et al. } \\
\text { (2019) }\end{array}$ & $\begin{array}{l}\text { 1996:1-2017:9 } \\
\text { (Turkey) }\end{array}$ & $\begin{array}{l}\text { DOLS and } \\
\text { FMOLS }\end{array}$ & $\begin{array}{l}\text { Crude Oil } \\
\text { Import } \\
\text { Demand }\end{array}$ & $\begin{array}{l}\text { DOLS: The long run price and income elasticities are - } \\
0.11 \text { and } 1.04 \text {, respectively. } \\
\text { FMOLS: The long run price and income elasticities are } \\
-0,11 \text { and } 1.02 \text {, respectively. }\end{array}$ \\
\hline
\end{tabular}

Table 2.2 Summary of Previous Crude Oil Demand Studies.

More recently, Görüş et al. (2019) examined the impacts of oil price and income on crude oil import demand for Turkey between the period 1996:1 and 2017:9. They used Fourier Shin 
cointegration test and Fourier Toda-Yamamoto approach to analyse the cointegration and causality relations among the parameters. In addition, they utilized the Dynamic Ordinary Least Squares (DOLS) and Fully Modified Ordinary Least Squares (FMOLS) methods to identify the long run elasticities. By using these long run elasticities, they established an Error Correction Model and estimated the short run coefficients. According to their findings, while the long run price and income elasticities are estimated as -0.11 and 1.04 in DOLS method, the results of the FMOLS approach are -0.11 for the price and 1.02 for the income. In addition, they found the income elasticity of crude oil as 0.35 and the price elasticity as statistically insignificant in the short term.

In Table 2.2, the summary of selected literature related to Turkey's crude oil import demand is given.

\section{METHODOLOGY AND DATA}

The methodology that applied in this study is Harvey's (1989) Structural Time Series Modelling (STSM) approach with the Underlying Energy Demand Trend (UEDT) concept. The UEDT concept introduced to energy demand literature by Hunt et al. (2000, 2003a, 2003b), and they argue that STSM method is a proper structure to model UEDT. Since the STSM methodology enables to estimate the UEDT, the changes in demand tendency can easily be observed in this model. Thus, it can be said that the STSM method is an appropriate approach to estimate the stochastic UEDT. In this approach, the UEDT enables to include technical change and the change in energy efficiency to the model in a non-deterministic way. As a result, the variations in consumer tastes and economic structure can be modelled in this approach. In addition, the price and income elasticities can be found as more unbiased than the conventional methods (Sa'ad, 2011).

The STSM approach can be formulated with an unobservable trend as in the following model:

$$
Y_{t}=\mu_{t}+Z_{t}^{\prime} \delta+\varepsilon_{t}
$$

where $Y_{t}$ is the dependent variable, $\mu_{t}$ is the trend component and $\varepsilon_{t}$ is the white noise disturbance term $\left(\varepsilon_{t} \sim N I D\left(0, \sigma^{2}\right)\right) . Z_{t}$ is $k \times 1$ vector of explanatory variables and $\delta$ is $k \times 1$ vector of unknown parameters. In this model, $\mu_{t}$ represents the unobservable trend parameter and have the following stochastic process:

$$
\begin{array}{cc}
\mu_{t}=\mu_{t-1}+\beta_{t-1}+\eta_{t} & \eta_{t} \sim N I D\left(0, \sigma_{\eta}^{2}\right) \\
\beta_{t}=\beta_{t-1}+\xi_{t} & \xi_{t} \sim N I D\left(0, \sigma_{\xi}^{2}\right)
\end{array}
$$

In here, the uncorrelated white noises disturbances $\mu_{t}$ and $\beta_{t}$ are level and slope components of the trend, respectively. Furthermore, $\eta_{t}$ and $\xi_{t}$ are the determinants of the change in the level and slope of the trend, respectively. The shape of the trend depends on the variances $\sigma_{\eta}^{2}$ and $\sigma_{\xi}^{2}$ which are called as hyperparameters. In STSM approach, the trend is said to be stochastic, if and only if these hyperparameters are both non-zero. If not, the model transforms into a conventional deterministic time trend regression. In addition, the level and slope disturbances $\left(\eta_{t}\right.$ and $\left.\xi_{t}\right)$ that given in Equation (3.2) and Equation (3.3) are assumed in normal distribution. Therefore, they should be included to the model where it is necessary to ensure the normality qualification of auxiliary residuals.

The main model that used in this study is as follows:

where;

$$
Q_{t}=f\left(Y_{t}, P_{t}, U E D T_{t}\right)
$$


$Q$ is the quantity of imported crude oil, $Y$ the real GDP and $P$ the real crude oil price. The crude oil import demand equation can be specified in econometric form as follows:

where

$$
\alpha(L) Q_{t}=\beta(L) Y_{t}+\theta(L) P_{t}+U E D T_{t}+u_{t}
$$

$\alpha(L)$ is polynomial lag operator, $1-\phi_{1} L-\phi_{2} L^{2}-\phi_{3} L^{3}-\phi_{4} L^{4}$ for $i=4$;

$$
\beta(L)=\sum_{i=0}^{m} \varphi_{i} L^{i}
$$

$\beta(L)$ is polynomial lag operator, $1+\varphi_{1} L+\varphi_{2} L^{2}+\varphi_{3} L^{3}+\varphi_{4} L^{4}$ for $i=4$;

$$
\theta(L)=\sum_{i=0}^{k} \lambda_{i} L^{i}
$$

$\theta(L)$ is polynomial lag operator, $1+\lambda_{1} L+\lambda_{2} L^{2}+\lambda_{3} L^{3}+\lambda_{4} L^{4}$ for $i=4$;

$Q_{t}=$ the natural log of crude oil import demand,

$Y_{t}=$ the natural log of income,

$P_{t}=$ the natural $\log$ of price,

$U E D T_{t}=$ the estimated value of the Underlying Energy Demand Trend at time $t$, $u_{t}=$ random white noise error term.

UEDT is the unobservable trend that involves technical changes (endogenous and exogenous) and other exogenous factors in energy demand such as preferences, tastes, economic structure, environmental issues, etc. Therefore, Hunt et al. (2003a) have strongly recommended the need for correctly estimated UEDT in the model to avoid the biased estimations of income and price elasticities. Table 3.3 presents the endogenous and exogenous technical factors that affect the energy demand and generate the UEDT.

\begin{tabular}{cccc}
\hline \hline \multicolumn{2}{c}{ Technical Energy Efficiency } & \multicolumn{2}{c}{ Consumer Tastes } \\
Endogenous & Exogenous & $\frac{\text { Economic Structure }}{\text { Exogenous }}$ & Exogenous \\
\hline \hline
\end{tabular}

Table 3.3 Underlying Energy Demand Trend

Source: Hunt et al. (2003a).

If there are no interventions to the model, the UEDT is equal to $\mu_{t}$ in Equation (3.5). However, if there are interventions, UEDT equals to the sum of $\mu_{t}$, level interventions, slope interventions and irregular interventions (Harvey and Koopman, 1992). In this context, the UEDT within the presence of these interventions can be defined as;

$$
U E D T=\mu_{t}+\text { level interventions }+ \text { slope interventions }+ \text { irregular interventions }
$$

Equation (3.9) presents the UEDT concept with interventions. These interventions gives information about structural breaks and changes for the specific period in the estimated models. In addition, the hyperparameters which are defined as $\sigma_{\eta}^{2}, \sigma_{\xi}^{2}$ and $\sigma_{\varepsilon}^{2}$ determine the shape of UETD. Furthermore, the proper interventions are chosen to add into the model for providing the normality conditions of the auxiliary residuals. While the level and slope interventions represent permanent impacts on the trend, the irregular interventions state the temporary effects. In brief, the model is estimated by considering these interventions to eliminate the statistically insignificant variables and pass the diagnostic tests.

Last but not the least, Kalman filtering approach (Kalman, 1960) is used in this study to estimate the dynamic equations of the STSM/UEDT model in the state space form. The hyperparameters are estimated by using the smoothing algorithm of the Kalman filter. In addition, the auxiliary and equation residuals are estimated for model selection process. Furthermore, Likelihood Ratio (LR) test is carried out to prove the difference between models which use deterministic and stochastic trend. 


\subsection{Data}

In this study, the annual data covering the period between 1970 and 2018 are used to determine the price and income elasticities of crude oil import demand for Turkey. The variables used in the model are specified as the quantity of imported crude oil, real GDP and real crude oil prices. The summary statistics of the variables are given in Table 3.4. All variables are transformed natural log forms to interpret the coefficient as elasticities. In addition, the US consumer price index data are used to convert nominal prices to the real ones.

The crude oil import (barrel) and oil prices (\$/per barrel) data were obtained from BP Statistical Review of World Energy 2019 report published by British Petroleum (BP, 2019). The real GDP in US dollars $(2010=100)$ and the Consumer Price Index $(2010=100)$ data were gained from World Development Indicators (World Bank, 2019). The econometric models were estimated by using STAMP 8.20 (Koopman et al., 2009) software programmer.

\begin{tabular}{lccc}
\hline \hline & $\begin{array}{c}\text { Crude oil import } \\
\text { (barrel) }\end{array}$ & $\begin{array}{c}\text { Real price of imported crude oil } \\
\text { (\$ per barrel) }\end{array}$ & $\begin{array}{c}\text { Real income } \\
\text { (billion \$) }\end{array}$ \\
\hline Mean & 529.65 & 50.01 & 498.62 \\
Median & 562.83 & 46.70 & 416.42 \\
Minimum & 136.22 & 10.10 & 146.77 \\
Maximum & 1013.28 & 107.85 & 1240.04 \\
Std. dev. & 224.47 & 27.46 & 304.50 \\
Skewness & 0.1838 & 0.6167 & 0.9164 \\
Kurtosis & 2.3803 & 2.3165 & 2.8326 \\
\hline \hline
\end{tabular}

Table 3.4 Summary Statistics of the Variables

\section{EMPIRICAL RESULTS}

In the STSM/UEDT approach, Equation (3.5) is estimated by considering the level and slope components, eliminating the statistically insignificant variables and ensuring the model to pass the diagnostic tests. Different from the conventional cointegration approaches, the short and long term elasticities of the demand can be estimated via one equation in the STSM method.

Choosing the optimal lag lengths of the variables is an important issue in econometric models. In this study, a four year lag is chosen to reflect the dynamic effects. Therefore, as it can be seen in methodology part of the study, the four year lag is determined for the polynomial lag operator. In addition, it is not necessary to check the series that used in the STSM/UEDT method by unit root tests since the order of integration for the variables does not matter. Therefore, the unit root test results will not be presented in this study. The detailed estimations for the coefficients and the level-slope values with the diagnostic test results are given in Table 4.5 .

The estimated equation for the Turkish crude oil import demand is as follows:

$$
Q_{t}=0.66 Y_{t}-0.11 P_{t}+U E D T_{t}
$$

where the price and income elasticities are found as -0.11 and 0.66 , respectively and statistically significant at the $1 \%$ level. In addition, the UEDT of the equation is -14.10876 with a slope of 0.07481 at the end of the period. The nature of the trend can be defined as local level, which means that only stochastic level component is included in the model. 


\begin{tabular}{|c|c|c|c|c|c|}
\hline \multicolumn{6}{|c|}{ Dependent Variable: $Q$} \\
\hline Variables & Coefficient & Standard Errors & \multicolumn{2}{|l|}{ T-value } & Prob \\
\hline$Y$ & 0.66190 & 0.14953 & \multicolumn{2}{|l|}{4.42654} & {$[0.00]$} \\
\hline$P$ & -0.11476 & 0.02045 & \multicolumn{2}{|l|}{-5.61172} & {$[0.00]$} \\
\hline Level Break 1973 & 0.12550 & 0.04518 & \multicolumn{2}{|l|}{2.77746} & {$[0.00]$} \\
\hline Slope Break 1979 & -0.08068 & 0.01538 & \multicolumn{2}{|l|}{-5.24400} & {$[0.00]$} \\
\hline \multicolumn{6}{|c|}{ Level and Slope Components of UEDT 2018} \\
\hline Level & $-14.10876[0.00000]$ & & & & \\
\hline Slope & $0.07481[0.00001]$ & & & & \\
\hline \multicolumn{2}{|r|}{ Residuals } & \multicolumn{4}{|c|}{ Auxiliary Residuals } \\
\hline & & & Irregular & Level & Slope \\
\hline Std. Error & 0.038617 & Std. Error & 1.0043 & 0.97605 & 0.65908 \\
\hline Normality & 0.41942 & Normality & 1.2557 & 0.79939 & 2.1913 \\
\hline Skewness & 0.11811 & Skewness & 0.51183 & 0.43175 & 1.9679 \\
\hline Kurtosis & 0.70395 & Kurtosis & 0.7439 & 0.36764 & 0.22342 \\
\hline$H(14)$ & 0.61281 & & & & \\
\hline$R(1)$ & -0.045176 & \multicolumn{3}{|l|}{ LR Test } & \\
\hline$R(7)$ & 0.18852 & \multirow{2}{*}{\multicolumn{3}{|c|}{$\begin{array}{l}\text { Test (a) } 14.03(0.00) \\
\text { Test (b) } 57.84(0.00)\end{array}$}} & \\
\hline$D W$ & 1.6230 & & & & \\
\hline$Q(7,5)$ & 8.1976 & \multicolumn{3}{|c|}{ Test (b) $57.84(0.00)$} & \\
\hline \multicolumn{2}{|c|}{ Predictive Test 2011-2018 } & \multicolumn{4}{|c|}{ Goodness of Fit } \\
\hline Failure & 6.7327 & $R^{2}$ & & 0.9791 & \\
\hline \multirow[t]{3}{*}{ Cusum t(8) } & 0.3791 & $R_{d}^{2}$ & & 0.6844 & \\
\hline & & P.E.V. & & 0.0014 & \\
\hline & & P.E.V./ (M.I & & 1.0258 & \\
\hline \multicolumn{2}{|c|}{ Hyperparameters } & & & & \\
\hline Irregular & 0.000276694 & & & & \\
\hline Level & 0.00119062 & & & & \\
\hline Slope & 0.00000000 & & & & \\
\hline
\end{tabular}

Table 4.5 The Results of STSM Method

Notes: 1. Model estimation is made in STAMP 8.20.

2. There are one level intervention dummy variable for the year 1973, and one slope dummy variable for the year 1979 in the model.

3. Error normality statistics of Bowman-Shenton Normality Test, Skewness and Kurtosis tests are all approximately distributed as $\chi^{2}$.

4. The goodness of fit of the model is shown by Prediction Error Variance $(P E V)$, Prediction Error Mean Deviation $\left(P E V /(M D)^{2}\right)$, and the Coefficient Determination $\left(R^{2}\right.$ and $\left.R_{d}^{2}\right)$.

5. $H(14)$ is the heteroscedasticity statistic.

6. $R(1)$ and $R(7)$ are the serial correlation coefficients at the $1^{\text {st }}$ and $7^{\text {th }}$ lag, respectively

7. $D W$ is the Durbin-Watson statistic.

8. $Q(7,5)$ is the Box-Ljung $Q$-statistics based on the first 7 residuals autocorrelations and distributed as $\chi^{2}(5)$.

9. Predictive test is made by STAMP and re-estimate the model up to 2010 and forecasting the period between 2011 and 2018. Failure is an estimated failure statistic and Cusum is a stability statistic of the model.

10. $L R$ Test(a) represent likelihood ratio tests on the same specification after imposing a fixed level and fixed slope hyperparameter and Test (b) after imposing a fixed level and zero slope; both are distributed as $\chi^{2}(2)$ and probabilities are given in parenthesis.

11. The hyperparameters determine the shape of the UEDT.

Thomas (1993) indicates that a number of criteria such as data coherency, consistency with theory, parsimony, encompassing and parameter consistency should be checked for establishing a model. Koopman et al. (2009) state that in order to control whether the structural time series models are meeting these criteria, the estimated models should pass specific diagnostic tests. In this study, several diagnostic tests were applied to analyse the consistency of the parameters and unbiasedness of the estimates. The Bowman-Shenton test is used for testing the normality of the series which utilises the skewness and kurtosis estimates of the regression. The estimated 
Bowman-Shenton test statistics are found lower than the critical values. Therefore, these results show that the error terms are normally distributed. Another important diagnostic test in econometric models is heteroscedasticity of residuals which analyses whether the constant variance assumption is valid. According to the probability value $(0.61281)$ of non-parametric $F$ test (two-sided) the null hypothesis of no heteroscedasticity can be rejected at the proper significance level and it can be said that the residuals have constant variance. In addition, there is no serial correlation or autocorrelation problem among the error terms of the regression based on the Durbin-Watson and Box-Ljung test statistics. This means that the disturbance terms are not correlated. The rest of the explanations related to the results are in the notes of Table 4.5.

As mentioned in the methodology part, the intervention dummy variables need to be added to the model for providing the normality of the auxiliary residuals. Therefore, two interventions are included in the model for the years 1973 and 1979. The model passes all diagnostic tests with a level intervention dummy for 1973, and a slope intervention dummy for 1979. The level intervention dummy for 1973 may represent the first oil shock in that year. In this period, the oil-producing countries decided to increase the prices. As a result of this move, oil prices increased from $3.60 \$ /$ barrel to $12.21 \$ /$ barrel in two years (McMahon, 2017). This sharp price increase in a very short period caused significant changes in the economies of oil-producing and consuming countries. This price movement is affected negatively to Turkey as an oil imported country. Hence, there were serious changes on budget balance and quantity of oil imports in that period.

The slope dummy for 1979 may present the second oil crisis. Again, the Organization of the Petroleum Exporting Countries (OPEC) increased the oil prices. While the price was 14.95 $\$ /$ barrel in 1978, it increased more than $65 \%$ and reached to the level of $25.10 \$ /$ barrel in 1979 and then went up to $37.42 \$$ /barrel in 1980 . Therefore, several developed and developing countries were faced with the international payment difficulties and finally external debt crises (Capistrano and Kiker, 1995).

Figure 4.3 UEDT $\left(\mu_{t}\right)$ for Turkey's Crude Oil Import Demand (1970-2018)

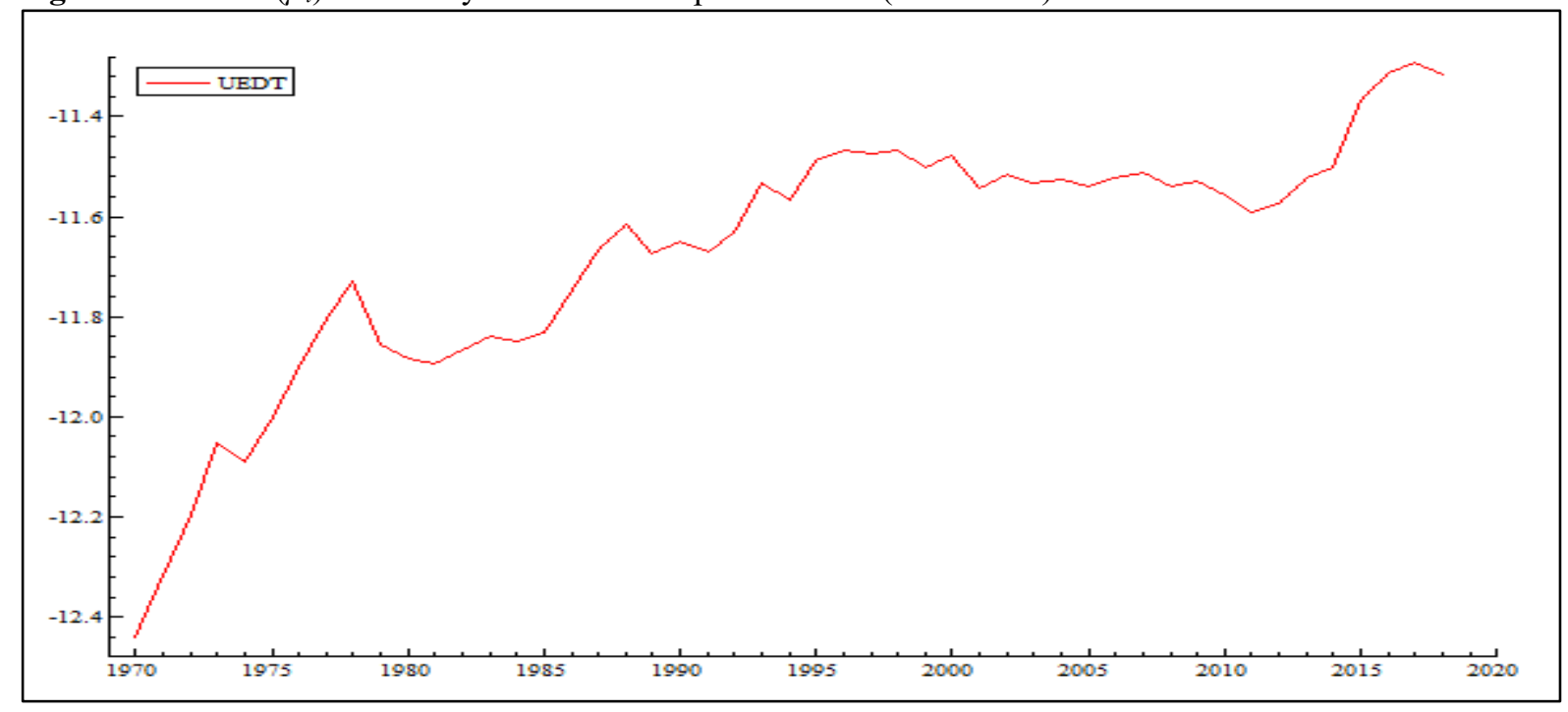

The estimated stochastic trend (UEDT) with the presence of these intervention dummy variables is illustrated in Figure 4.3. It is seen from the graph that the shape of the trend shows a fluctuating process since the estimated UEDT rises and diminishes over the estimation period. However, there is an upward trend which can be demonstrated as the increase in crude oil demand between 1970 and 2018. 
Lastly, the stability of the parameters is checked by using cumulative sum (CUSUM) and cumulative sum of squares (CUSUSMQ) tests. The graphs of CUSUM and CUSUMQ tests are presented in Figure 4.4. According to the results, all coefficients are stable over the sample period.

Figure 4.4 CUSUM and CUSUMQ Plots for the Estimated STSM/UEDT Model

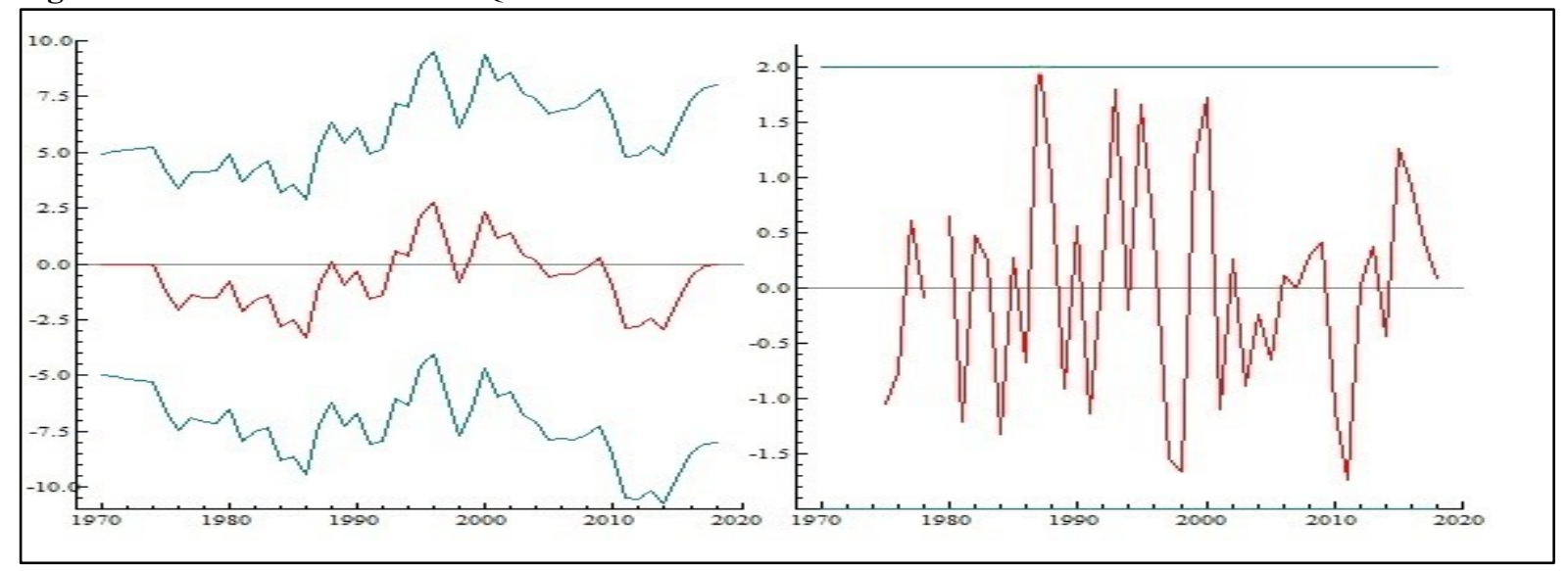

\section{CONCLUSION}

Energy is a derived demand which is not demanded for its own sake. In this sense, there are various exogenous factors that affect the energy demand. Therefore, without taking into consideration of these effects, the estimation results may be spurious. Estimation of the exogenous variables, such as technical progress, consumer tastes, and economic structure is quite difficult in a linear framework. However, the flexible structure of the STSM/UEDT concept enables to measure the effects of these exogenous variables. In addition, through the estimated UEDTs, the unobserved energy demand trend can be seen by holding income and price constant. Consequently, this situation provides an advantage to analyse the exogenous factors that affect the energy demand behaviour.

For these purposes, the STSM method with the UEDT concept is used in this study to analyse the price and income elasticities of imported crude oil demand in Turkey for the period of 19702018. Empirical findings suggest that the price and income elasticity estimates are statistically significant. In addition, the diagnostic tests confirm that the findings are reliable and consistent. According to the results of this study, the price and income elasticities of crude oil import demand are -0.11 and 0.66 , respectively. In the light of these results, both of the elasticities (price and income) for the imported crude oil demand are said to be inelastic. This results show parallelism with the findings of some similar research in the literature like Altinay (2007), Yapraklı and Kaplan (2015). In addition, two dummy variables were included in the model to see the effects of global oil shocks on the crude oil demand in Turkey. These dummy variable represents the two major global oil crises in 1973 and 1979. Therefore, it can be concluded that these external crises had significant impacts on crude oil import demand in Turkey.

Income and price have particular impacts on Turkey's crude oil demand elasticity. In the context of elasticity estimates of this research, income was found more than that of price. This means that the effect of income on crude oil import demand is more than the price in Turkey. On the other hand, since oil is a necessity good in today's world, the price elasticity is quite low. This means that Turkey's crude oil import is less responsive to the changes in price. 
The results of this study show that according to the elasticity estimates, crude oil is in the category of necessary goods for Turkey. However, Turkey is mostly dependent to the external suppliers on this energy resource. This situation generates several risks in terms of energy supply security. Moreover, Turkey's energy spending rises when the price of crude oil increases in the market. The elasticity estimates of this study present that Turkey's crude oil demand have not changed a lot based on the fluctuations in the global oil prices. This means that a shock in oil prices (extreme increase in price) will definitely damage Turkey's economy and have a strong adverse effect on the trade balance. To protect the country from the negative impacts of the price shocks, the oil storage capacity of Turkey should be enlarged. By doing so, Turkey can take a possibility to compete the global price in the domestic market. This enables the country to increase the energy supply security and competitive power.

In addition, inelastic price elasticity of crude oil demand in Turkey gives an important opportunity to the authorities in taxation policy. That is to say, government can determine the tax rate on oil elastically to control the oil demand. However, since the oil is a necessity good in Turkey, the level of the tax rates will not affect the consumption excessively. Therefore, while the import prices, taxes and additional expenses are directly reflected to the final tariffs, the consumers have to meet these costs. Therefore, if the cheap oil can be collected from the markets and stored in Turkey then the domestic prices can be balanced.

On the other hand, although price and income are assumed as a linear functions of crude oil import demand, they are affecting the demand in different ways. While the price effect of demand is negative, any increase in income push the oil demand high. In this sense, the findings of this study suggest that a $1 \%$ increase in GDP increases the crude oil demand by $0.66 \%$. This means that Turkey's crude oil demand is parallel but lower than that of the increase in GDP.

Consequently, it is important to analyse what drives the crude oil import demand and how the future demand might change for the dependent countries like Turkey. The priorities of Turkey in the field of imported oil are ensuring the security of oil supply, decreasing the expenditures, increasing the domestic production in oil and having a critical position in global oil markets. As part of these priorities, it is believed that the findings and comments of this study provide some critical information for policy makers to find sustainable and cost efficient solutions for problems of meeting future oil demand in Turkey.

\section{REFERENCES}

Altınay, G. (2007). Short-Run and Long-Run Elasticities of Import Demand for Crude Oil in Turkey. Energy Policy, 35 (11), 5829-5835.

BP (2019). Statistical Review of World Energy 2019. British Petroleum (BP) Website. https://www.bp.com/en/global/corporate/energy-economics/statistical-review-of-worldenergy.html (accessed January 15, 2020).

Capistrano, A.D. and C.F. Kiker (1995). Macro-Scale Economic Influences on Tropical Forest Depletion. Ecological Economics, 14 (1), 21-29.

Dash, D.P., N. Sethi and D.P. Bal (2018). Is the Demand for Crude Oil Inelastic for India? Evidence from Structural VAR Analysis. Energy Policy, 118, 552-558. 
Fatima, T., E. Xia and M. Ahad (2019). Oil Demand Forecasting for China: A Fresh Evidence from Structural Time Series Analysis. Environment, Development and Sustainability, 21 (3), 1205-1224.

Ghosh, S. (2009). Import Demand of Crude Oil and Economic Growth: Evidence from India. Energy Policy, 37 (2), 699-702.

Görüş, M.S., Ö. Özgür and A. Develi (2019). The Relationship between Oil Prices, Oil Imports and Income Level in Turkey: Evidence from Fourier Approximation. OPEC Energy Review, 43 (3), 327-341.

Harvey, A.C. (1989). Forecasting, Structural Time Series Models and the Kalman Filter. Cambridge, UK: Cambridge University Press.

Harvey, A.C. and S.J. Koopman (1992). Diagnostic checking of unobserved-components time series models. Journal of Business \& Economic Statistics, 10 (4), 377-389.

Hunt, L.C., G. Judge and Y. Ninomiya (2000). Modelling Technical Progress: An Application of the Stochastic Trend Model to UK Energy Demand. Surrey Energy Economics Discussion Paper SEEDS, No: 99.

Hunt, L.C., G. Judge, and Y. Ninomiya (2003a). Modelling Underlying Energy Demand Trends, Surrey Energy Economics Discussion Paper, No. 105, 1-40. Surrey Energy Economics Centre (SEEC), Department of Economics, University of Surrey, Guildford, UK.

Hunt, L.C., G. Judge, and Y. Ninomiya (2003b). Underlying Trends and Seasonality in UK Energy Demand: A Sectoral Analysis. Energy Economics, 25 (1), 93-118.

Kalman, R.E. (1960). A new approach to linear filtering and prediction problems. Journal of Basic Engineering, 82, 35-45.

Khalil Jebran, A., M.M. Elhabbaq, A. Ali (2017). Income and Price Elasticities of Crude Oil Demand in Pakistan. Global Business Review, 18 (6), 1373-1383.

Koopman, S.J., A.C. Harvey, J.A. Doornik and N. Shephard (2009). STAMP 8.2: Structural Time Series Analyser, Modeler, and Predictor. London: Timberlake Consultants.

McMahon, T. (2017). Historical Crude Oil Prices, Inflation Data, Inflation Data Website. https://inflationdata.com/articles/inflation-adjusted-prices/historical-crude-oil-prices-table (accessed February 20, 2020).

MENR (2018). Ministry of Energy and Natural Resources - Energy Balance Sheets (in Turkish translated by author). MENR Website. http://www.eigm.gov.tr/tr-TR/Denge-Tablolari /Denge-Tablolari (accessed March 5, 2020).

Öztürk, İ. and İ. Arısoy (2016). An Estimation of Crude Oil Import Demand in Turkey: Evidence from Time-Varying Parameters Approach. Energy Policy, 99, 174-179. 
Sa'ad, S. (2011). Underlying Energy Demand Trends in South Korean and Indonesian Aggregate Whole Economy and Residential Sectors. Energy Policy, 39 (1), 40-46.

Sadorsky, P. (1999). Oil Price Shocks and Stock Market Activity. Energy Economics, 21 (5), 449-469.

Solak, A.O. and A. Beşkaya (2013). Türkiye'nin Net Petrol İthalatının Fiyat ve Gelir Esneklikleri: ARDL Modelleme Yaklaşımı ile Eşbütünleşme Analizi. [Price and Income Elasticities of Net Oil Imports in Turkey: An ARDL Modelling Approach to Cointegration Analysis]. Uluslararası Yönetim İktisat ve İşletme Dergisi, 9 (18), 19-29.

Thomas, R. (1993). Introductory Econometrics: Theory and Applications, $2^{\text {nd }}$ Edition. London: Longman.

Yaprakl1, S. and F. Kaplan (2015). Re-Examining of the Turkish Crude Oil Import Demand with Multi-Structural Breaks Analysis in the Long-Run Period. International Journal of Energy Economics and Policy, 5 (2), 402-407.

World Bank (2019). World Development Indicators. World Bank Website. http://databank .worldbank.org/data/reports.aspx? source $=2 \&$ country=TUR (accessed January 15, 2020).

Ziramba, E. (2010). Price and Income Elasticities of Crude Oil Import Demand in South Africa: A Cointegration Analysis. Energy Policy, 38 (12), 7844-7849. 